\title{
Can Vacuum assisted wound management enhance graft acceptance?
}

Astrid B. M. Rijkenhuizen, Robin van den Boom, Marco Landman* und Brigitte P. M. Cornelissen

Department of Equine Sciences, Utrecht University and private practitioner Glas Diergeneeskunde BV*

\begin{abstract}
Summary
Vacuum-assisted wound closure (VAC), a novel innovation in wound-care, has been proven to promote wound healing in human medicine and was recently also described for the treatment of a neck wound in a horse. It ensures adequate wound drainage, a moist woundhealing environment, increased rate of granulation tissue formation, improved blood flow and reduced bacterial count. The results of the application of VAC as a supportive therapy in skin grafting are encouraging in human patients with take rates of grafts above $90 \%$. The question is whether these results can also be obtained in horses. This article reports the clinical application of VAC in combination with the Meek micrografting method in 2 equine patients. The VAC provided adequate wound drainage, good fixation of the graft to the recipient site, limited shear forces and allowed graft acceptance of at least $75 \%$ in both patients. Although no control studies were conducted, the clinical results suggest that vacuum-assisted closure stimulates the acceptance of split thickness grafts and accelerates wound healing and may become an essential part of wound treatment in the future.
\end{abstract}

Keywords: surgery, traumatology, woundtreatment, skin grafting, vacuum assisted

\section{Kann der vakuumassistierte Wundverschluss die Einheilung von Spalthauttransplantaten fördern?}

Der vakuumassistierte Wundverschluss (VAC Vacuum Assisted Closure) fördert beim Menschen nachgewiesenermaßen die Wundheilung. Die Technik besteht in der Einwirkung eines definierten, kontrollierten Vakuums auf die Wundoberfläche. Die Folgen sind eine Verbesserung der lokalen Durchblutung und der Granulationsgewebsbildung, Reduzierung der Keimzahl und die Erhaltung eines feuchten Wundbereichs. Durch das kontinuierliche Absaugen extravaskulärer, interstitieller Flüssigkeit wird die Mikrozirkulation gefördert und durch den mechanischen Effekt des Vakuums auf die Wundoberfläche wird die Proliferation der Zellen stimuliert. Die Resultate der VAC als Unterstützung bei Spalthauttransplantation in der Humanmedizin sind mit der Einheilung des Transplantats bis über $90 \%$ ermutigend. Die Technik könnte auch in der Pferdetraumatologie einen wertvollen Beitrag zur Verbesserung der Heilung komplizierter Wunden leisten. Die Erfahrungen der Vakuumtherapie als ergänzende Therapiemaßnahme der Spalthauttransplantation wird hier bei zwei Pferden (einem Fohlen mit einer Wunde der Bauchwand und einem Pferd mit nodulärer Nekrobiose) beschrieben. Durch die Anwendung der Vakuumtherapie konnte ein kontinuierliches Absaugen von Wundflüssigkeit, gute Fixierung des Transplantats im Wundbett, limitierte Bewegung des Transplantats, Beschleunigung der Granulation und eine Einheilung von mindestens 75\% des Transplantats erreicht werden. Obschon Kontrolltiere fehlen, ergeben die klinische Resultate, dass vakuumassistierter Wundverschluss die Akzeptanz der Spalthauttransplantation stimuliert und die Wundheilung fördert. Möglicherweise wird der vakuumassistierte Wundverschluss in Zukunft beim Pferd ein unverzichtbarer Bestandteil in der Wundbehandlung werden.

Schlüsselwörter: Traumatologie, Chirurgie, Wundbehandlung, Vakuum, vakuumassistiert, Hauttransplantation

\section{Introduction}

Vacuum-assisted wound closure (VAC), a novel innovation in wound-care, has been proven to promote wound healing in human medicine and was recently also described for the treatment of a neck wound in a horse (Gemeinhardt and Molnar 2005). The wound bed is exposed to negative pressure using a closed system to hasten wound healing in a controlled environment. This technique ensures adequate wound drainage, a moist wound-healing environment, increased rate of granulation tissue formation, improved blood flow and reduced bacterial count (Ilizarow et al. 1989, Arengenta and Morykwas 2000, Morykwas et al. 2001, Banwell and Teot 2003, Saxena 2004, Tan et al. 2004). The results of the application of VAC in human medicine as a supportive therapy in skin grafting are encouraging (Argenta and Morykwas 1997, Blackburn et al. 1998, Schneider et al. 1998, Hallberg and Holmstrom 2003, Moisidis et al. 2004, Wackenfors et al. 2004). In human patients increased acceptance take rates of grafts above $90 \%$ at unfavourable graft recipient sites have been reported using VAC (Blackburn et al. 1998, Avery et al. 2000, Banwell and Teot 2003).

This article reports the clinical application of VAC in combination with the Meek micrografting method in 2 equine patients.

\section{Technique of Vacuum assisted wound closure}

The skin is shaved for at least $10 \mathrm{~cm}$ around the skin-edges and degreased with 70\% alcohol. The wounds are debrided when necessary and prepared for the skin graft. After ancho- 
ring the transplant a piece of sterile polyurethane foam with an open-cell structure (sponge $\mathrm{KCl}$ Medical B.V., Bergveste 12,3992 DE Houten) with a pore size ranging from 400 to $600 \mu \mathrm{m}$ (available in various sizes) is cut to the approximate size of the wound and positioned over the entire wound area. Care is taken to avoid overlap of the skin with the foam.

A sheet of the transparent adhesive drape (VAC, drape, $\mathrm{KCl}$ ) is used to cover the foam and fixed to the degreased dry skin with the use of Leucospray (BSN Medical, Postbus 1376, 1300 BJ Almere, Netherlands). A draining tube with side ports is embedded in the foam, ensuring equal distribution of the applied negative pressure, and connected to a vacuum-pump via a canister. Because the volume of wound fluid produced in equines exceeds that generated in human patients, a larger canister $(500 \mathrm{ml}$ instead of $300 \mathrm{ml})$ is used. The canister is attached to the abdominal bandage in an upright position (Fig. 1).

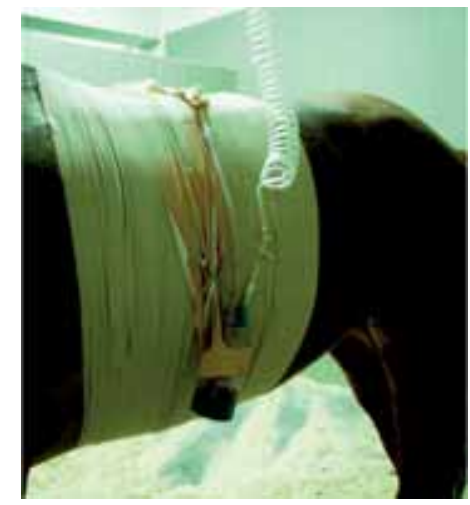

Fig 1 Patient with nodular necrobiosis on his back (case 2), showing the canister attached to the abdominal bandage.

Patient mit nodulärer Nekrobiose am Rücken (Fall 2) mit am Bauchverband befestigtem Kanister.

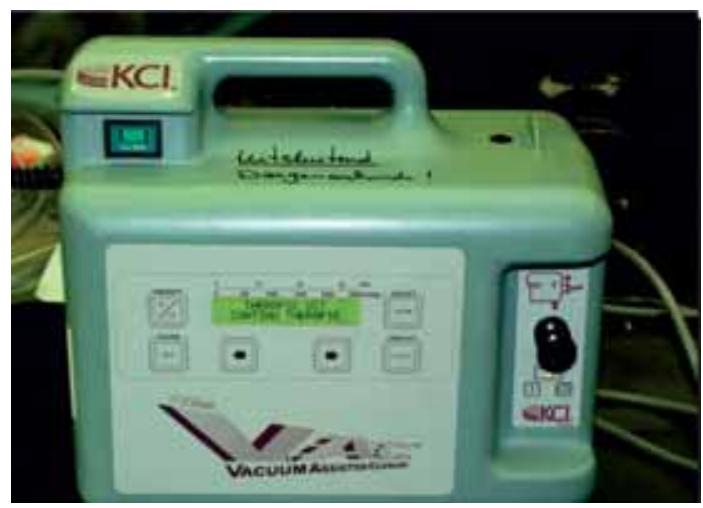

Fig 2 The VAC pump.

Die Vakuumpumpe

The drainage tube is connected to spiral tubing (Transparant Poly-Amide coiled tubing, working length 4 meters, uncoiled length 7 meters, inside diameter 4 millimeters, Brinkoflex, Postbus 97, 7480 AB, Haaksbergen, Netherlands) using rotating adaptors (swivel connector) to prevent tangling of lines, directed via the ceiling towards the pump $\left(\mathrm{VAC}^{\circledR}, \mathrm{KCl}\right.$ Medical B.V., Bergveste 12, 3992 DE Houten) that provides 125 $\mathrm{mmHg}$ of continuous negative pressure (Fig. 2). This system allowes the horse to move around in its stable. Once the vacuum is switched on, the air is sucked out of the foam causing it to collapse inwards (Fig 3). Covering the wound with an occlusive adhesive drape converts the open wound into a closed wound in a controlled environment.

\section{Case studies}

Case 1

A 9-month old Dutch Warmblood filly was referred to the Department of Equine Sciences with a large, fresh wound on its right abdominal and thoracic wall. The wound was the result of the foal jumping onto a metal fence. No deep structures were damaged, only skin and muscle were involved. Caudally a large, loose skin flap was present. Two unsuccessful attempts were made to surgically re-attach the skin flap to the abdominal wall and after 7 weeks it was decided to treat the wound using a modified Meek transplantation technique (postage stamp autografts) combined with VAC. At that stage the wound was triangular in shape with a dorsoventral base of approximately $26 \mathrm{~cm}$ caudally and extending $24 \mathrm{~cm}$ cranially (Fig 4). The wound was healing by second intention and the caudal part was covered by a loose skin flap

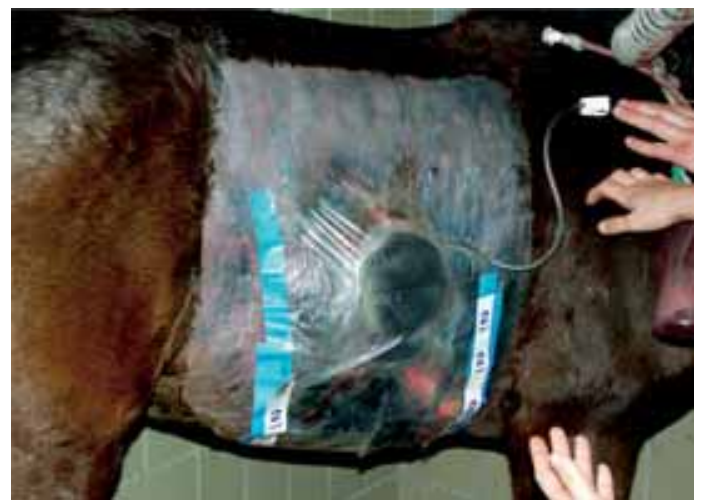

Fig 3 Foam covered with adhesive drape before (a) and after (b) the vacuum pump have switched on.

Mit Adhäsivverband bedeckter Schaum vor und nach Anschluss der Vakuumpumpe.

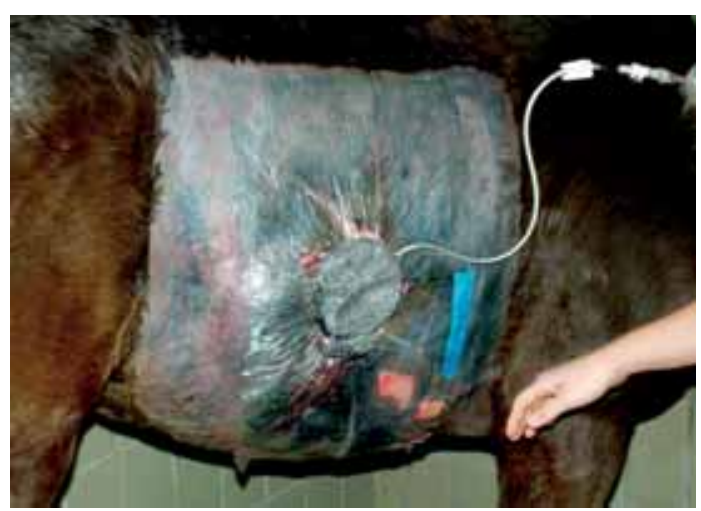

of $16 \mathrm{~cm}$ by $9 \mathrm{~cm}$. The horse was positioned in lateral recumbency under general anaesthesia. The loose skin flap was debrided and attached to the underlying tissue and surrounding skin (interrupted sutures using Monocryl ${ }^{\circledR}$ (Poliglecaprone 25)) leaving a drainage tract in the cranial part of the wound which had to heal per secundam. The cranial section was also debrided and covered with split-thickness skin grafts generated by the Meek micrografting method (Meek 1958, Kreis et al 1993) using skin harvested from the ventral part of the right thorax. The gauze with the graft was secured to the wound-bed and surrounding skin with monofilament resorbable material (Monocryl 2-0). To close the defect 3 expanded gauzes were implanted (Fig 5). The wound was covered with the foam and the transparent adhesive drape. The VAC pump was connected and an abdominal elastic bandage 
(Cutisorb $^{\circledR} 10 \times 20 \mathrm{~cm}$, Elastoplast ${ }^{\circledR} 4,5 \mathrm{~m} \times 10 \mathrm{~cm}$ ) was applied with the foal still under general anaesthesia, by lifting the patient with an electric hoist. During the recovery period the pump was briefly disconnected, but reconnected immediately once the filly was brought to its stable. Because the foal was very keen on biting the wound a wooden neck cradle was applied to limit flexion of the neck. Also, the foal was tied to the stable wall using a halter rope, but in such a way that it was able to lie down. Unfortunately, in the lying position the canister slanted and fluid entered the spiral tubing. A shorter rope was used, but the foal was still able to reach the bandage and loosen it little by little, causing air leakage, thus loosing the negative pressure.

The bandage and foam were changed on days 8, 11 and 14 after surgery. Initially, about $300 \mathrm{ml}$ of (hemorrhagic) wound fluid was collected daily but the volume declined to $30 \mathrm{ml}$

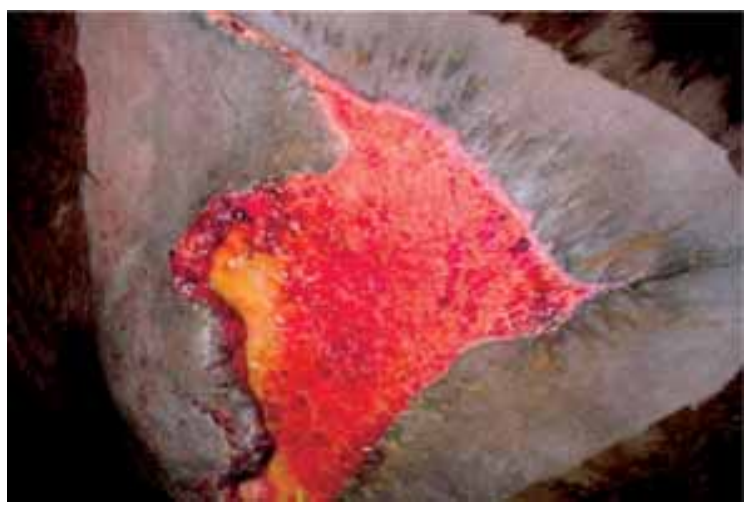

Fig 4 Right abdominal wall of the foal. The wound at that stage had a triangle form with a dorsoventral base approximately $26 \mathrm{~cm}$ caudally and extending $24 \mathrm{~cm}$ cranially.

Ansicht der rechten Bauchwand des Fohlens. Die Wunde hat zu diesem Zeitpunkt eine dreieckige Form mit einer Basis von ungefähr $26 \mathrm{~cm}$ kaudal und $24 \mathrm{~cm}$ nach kranial reichend.

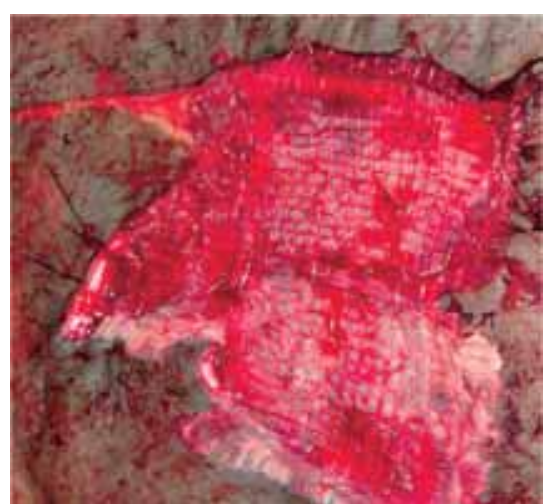

Fig 5 Right abdominal wall of the foal after debridement and securing the split thickness graft to the skin.

Rechte Bauchseite des Fohlens nach Debridement und Anheften der Spalthautlappen an die Haut.

(slightly hemopurulent) the day of disconnection of the pump. Antibiotics (Sultrisan ${ }^{\circledR}$ Orale Pasta, Trimetoprim/sulfadiazine, Anisane Pet Health Products, Raamdonksveer, the Netherlands, $1 \mathrm{ml} / 20 \mathrm{~kg}$ BW twice daily orally) were administered for 14 days and NSAID's for one week (Metacam ${ }^{\circledR}$, Meloxicam, Postbus 8037, 1802 KA Alkmaar Boehringer Ingelheim, 0,6 $\mathrm{mg} / \mathrm{kg}$ BW once daily orally). Due to its character the filly had to be sedated when changing the bandage (Domosedan ${ }^{\circledR}$ detomidinehydrochloride, 0,5 ml i.v. Pfizer Animal Health BV. 2900 AA Capelle a/d IJssel and Nubain ${ }^{\circledR}$ nalbuphinehydro- chloride $10 \mathrm{mg} / \mathrm{kg}$ i.v. Bristol-Meyers Squibb BV, Vijzelmolenlaan 3447 GX Woerden). After 19 days air-leakage occurred and the bandage and foam had to be removed. The hemopurulent exsudate was mainly generated by the part of the
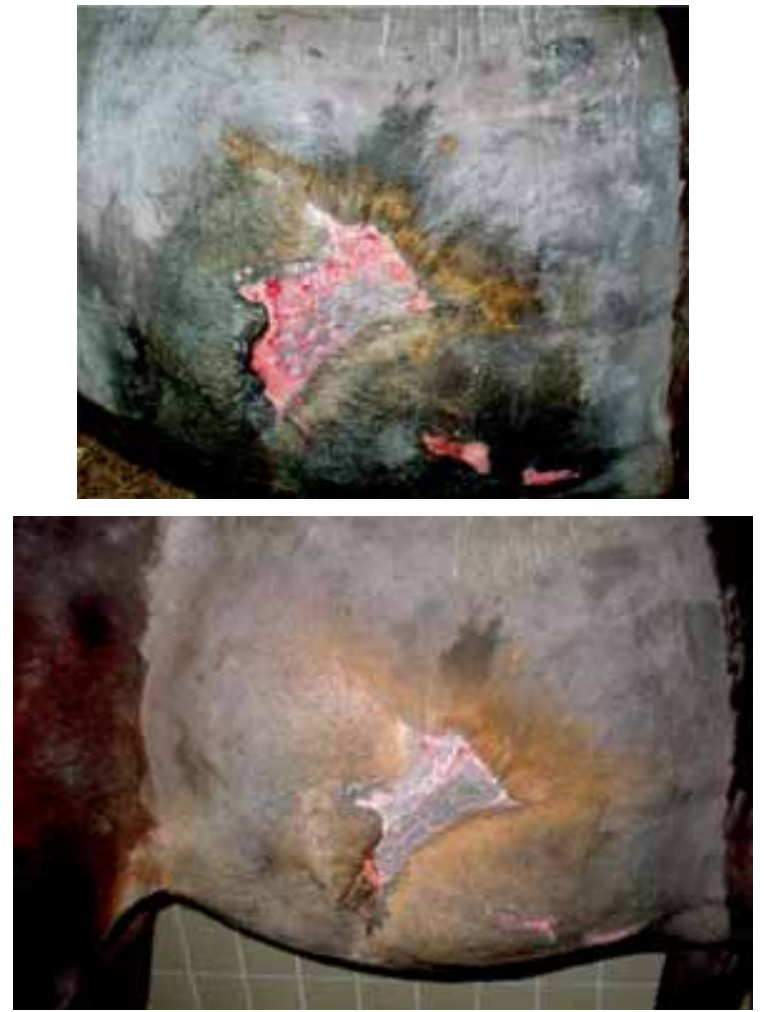

Fig 6 Right abdominal wall of the foal (case 1). a: 19 days after surgery. The graft take is about $80 \%$. b: 4 Weeks after surgery. The wound is almost epithelialized. c: 2 months after surgery. The wound is epithelialized and hair growth is visible.

Rechte Bauchwand des Fohlens (Fall 1). a: 19 Tage p.op. Die Transplantataufnahme liegt bei $80 \%$. b: 4 Wochen p.op. Die Wunde ist fast vollständig epithelisiert. c: 2 Monate p.op. Die Wunde ist epithelisiert und die Haare beginnen zu wachsen.

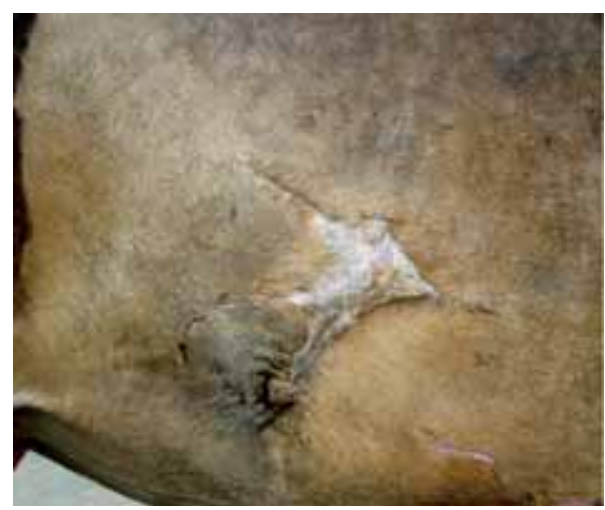

wound healing by second intention, at the distal end of the flap. As the graft was firmly attached to the underlying tissue it was decided not to replace the bandage. The wound had decreased in size, the flap was attached to the underlying tissue, the graft had taken for at least $80 \%$ and epithelialization was present. The wound had a pink granular appearance and was granulated to a level equal to the surrounding skin. At the ventral aspect of the skin flap was a small drainage tract was present. The defects at the donor site were filled with pink granulation tissue and a small amount of purulent exsudate was present. The sutures were removed. 
The foal was tied to the stable wall for another 6 days and the remainder of the wound was treated with ultraviolet light for 10 days, starting for 10 seconds on the first day, and increasing the treatment time with 10 seconds every day. Ten days after removal of the wound coverage the wound had epithelialised entirely and there was even hair visible on the transplanted skin (Fig. 6). At that time the patient was discharged from the hospital.

\section{Case 2}

A five-year old Dutch Warmblood horse was referred to the Department of Equine Sciences because of a bumpy skin disease, mainly on its back, which had been present for at least one year (Fig. 7). The nodules varied in size (average 2 $4 \mathrm{~cm}$ ) and consistency but crusts and purulent drainages were often present. The lesions were not painful but their location prevented the the horse from bearing a saddle without disrupting the skin over the bumps. Bacterial culture was positive for Streptococcus epidemicus and Staphylococcus aureus. After 6 weeks of rest the infection had resolved, the skin was intact and surgery was performed. Many solitary nodules were completely excised, but on either side of the

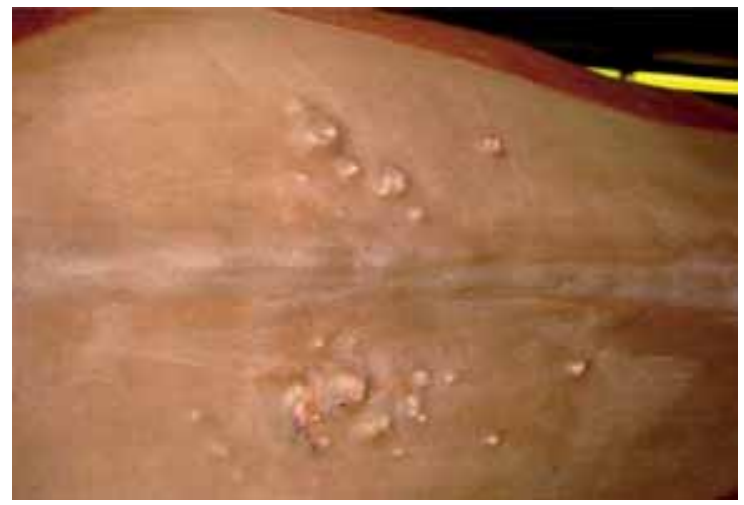

Fig 7 Patient with nodular necrobiosis on his back. View on his back.

Ansicht der Rückenpartie von Pferd 2 mit nodulärer Nekrobiose.

midline a large area of full thickness skin had to be removed down the fascia covering the muscles underneath, leaving defects of $7 \times 14$ and $8 \times 15 \mathrm{~cm}$ on the left and right side respectively.The defects were covered using the modified Meek transplantation technique. The expanded graft was secured to the underlying tissue with Monocryl ${ }^{\circledR}$ and protected during recovery by a pressure bandage.

Directly after recovery from anesthesia the bandage was removed and the foam, adjusted to the geometry of the wounds, was positioned over the wounds. Because there were two wounds, one on either side of the back, a foam bridge crossing the dorsal spinous processes on the left and right sides was connected with an additional foam positioned over a nonadhering gauze dressing (Adaptic ${ }^{\circledR}$ Johson and Johson). A drainage tube was implanted in the foam and connected to the VAC device. The foam was covered with the adhesive drape (Fig 8), which in turn was covered with absorbant pads (Cutisorb ${ }^{\circledR}$ BSN Medical) to prevent the abdominal bandage (adhesive elastic bandage Elastoplast ${ }^{\circledR}$ BSN Medical) becoming attached to the adhesive drape.

The horse was tied to the stable wall during the next 3 weeks to prevent the horse from lying down. Antibiotics (Trimeto- prim/sulfadiazine, $1 \mathrm{ml} / 20 \mathrm{~kg}$ BW twice daily orally) were continued for 17 days, starting preoperatively and NSAID's for 5 days (Meloxicam, 0,6 mg/kg BW once daily orally). The first two days following surgery the horse was somewhat restless. On the first post-operative day $40 \mathrm{ml}$ of wound fluid was collected, and this increased to $250 \mathrm{ml}$ a day, the fluid having a hemorrhagic appearance. The VAC foam dressing was changed after 11 days under sedation with Domosedan and Nubain. On day 18 the bandage was removed and the sutures were taken out. At the first dressing change it was noticeable that the grafts were firmly attached to the recipient bed. By the time the dressing was removed the wound had decreased in size by about $20 \%$ and approximately $80 \%$ and $75 \%$ of the graft had taken on the left and right side respectively (Fig 9a). The wound had a pink granular appearance and was granulated to a level equal to the surrounding skin. At both dressing changes the wounds had a wet aspect. Five weeks after surgery the wounds had healed completely and hair growth was visible (Fig 9b). The horse was allowed riding exercise two months later, which was accepted well by the horse and its skin (Fig 9c). Histological examination of the resected bumps revealed nodular eosinofilic panniculitis.

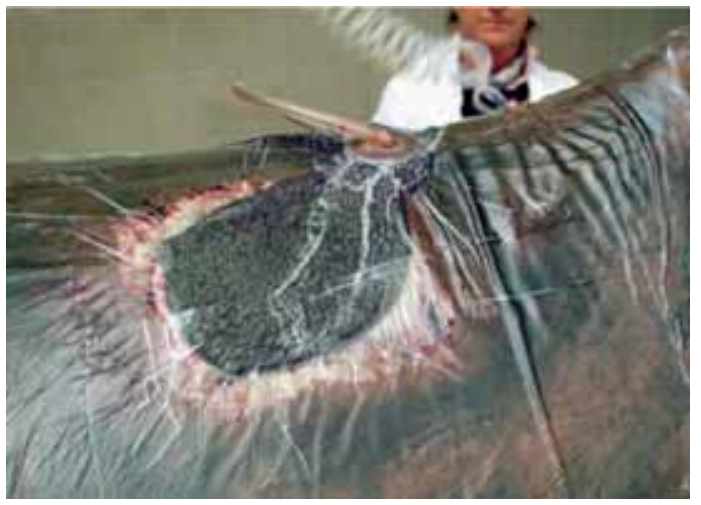

Fig 8 Patient with nodular necrobiosis on his back. The foam is positioned in the wound and covered with transparent adhesive drape. The VAC pump is switched on with a negative pressure of $125 \mathrm{mmHg}$.

Patient mit nodulärer Nekrobiose am Rücken. Der Schaum liegt im Bereich der Wunde und ist mit transparentem Adhäsivverband bedeckt. Die Vakuumpumpe ist angeschlossen und auf einen Negativdruck von $125 \mathrm{mmHg}$ eingestellt.

\section{Discussion}

There is reason to believe that application of VAC to enhance split thickness graft acceptance was successful in both patients. Both grafts where positioned in locations with a high degree of skin displacement over the underlying muscle. Appropriate contact between the skin graft and the recipient bed is critical to the survival of a graft and hematoma formation or graft movement can compromize graft acceptance. VAC provided adequate wound drainage and allowed graft take of at least $75 \%$ in both patients. At the first bandage change it became clear that this system evenly and continuously distributed pressure over the wound area and secured the transplanted skin firmly against the recipient site.

The main difficulty encountered was maintenance of an airtight seal. Shaving of the wound edges over a large area (at 
least $10 \mathrm{~cm}$ beyond the surgical field), degreasing of the skin and additional application of glue (Leukospray ${ }^{\circledR}$ ) before the adhesive drape was positioned on totally dry wound edges all proved essential. For this matter the use of Domosedan ${ }^{\circledR}$ can

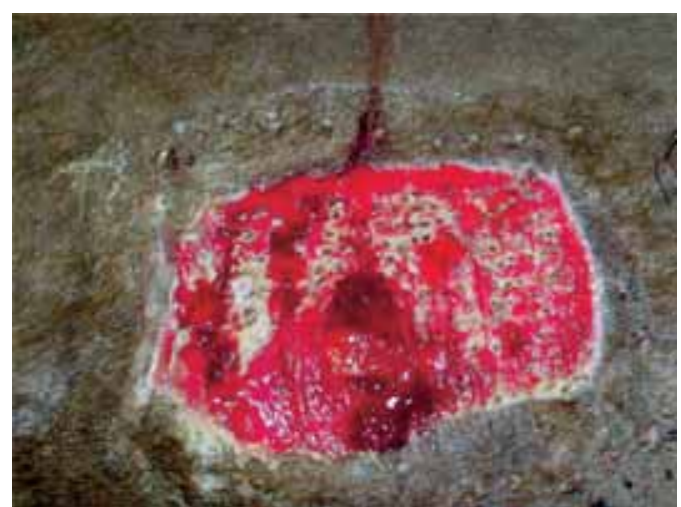

Fig 9 Patient with nodular necrobiosis on his back 18 days (a), 5 weeks (b) and 2 months (c) postoperative showing graft acceptance of 75 and $80 \%$ respectively (a) and the epithelization. Transplantataufnahme und Epithelisation des Patienten mit nodulärer Nekrobiose am Rücken 18 Tage (a), 5 Wochen (b) und 2 Monate (c) p.op.
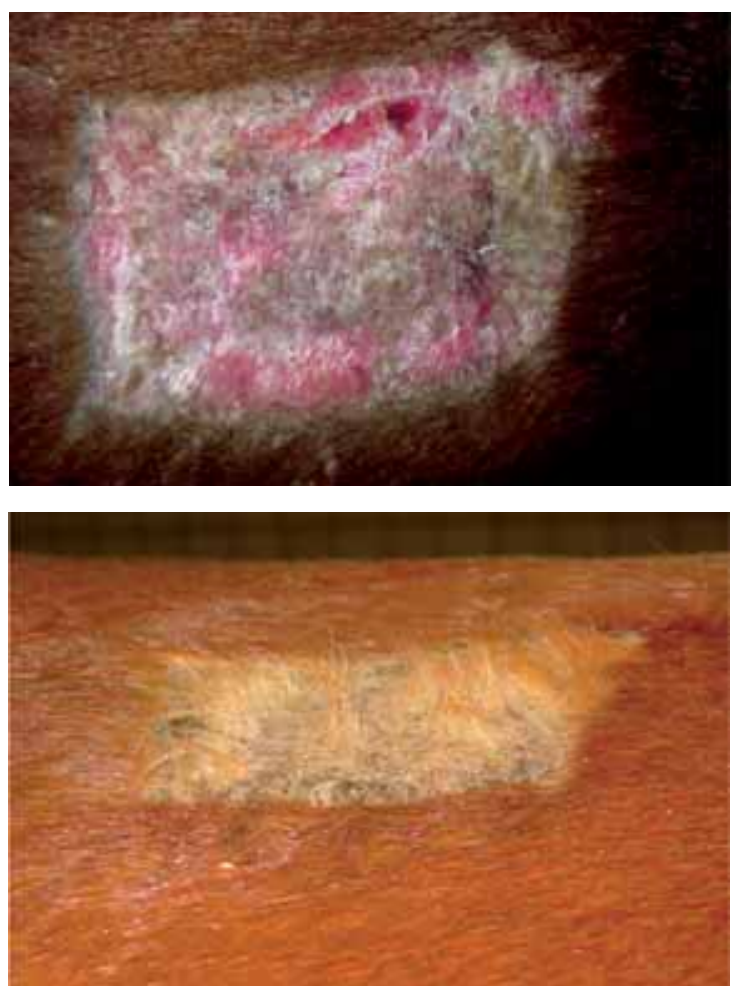

be contra-productive because of the sweating most horse show in response to it. The presence of even a minimal amount of wound fluid on the surrounding skin can cause air leakage and when wound fluid was noticed at the time of bandaging the sealing procedure was repeated to facilitate the build up of the vacuum. Any air leakage results in dehydration and necrosis instead of an increase in the rate of granulation tissue formation (Argenta et al 2001).

A second problem which had to be solved was allowing the horse to move around without disrupting the drainage system. The use of the spiral tubing with rotating adaptors to prevent tangling of lines functioned well. As a result of this construction fluid had to evacuated to the ceiling over a long distan- ce. To overcome this problem a canister was inserted into the system near the wound and fixed to the bandage covering the skin transplant. To prevent the canister from tilting and subsequent exsudate from entering the spiral tubing, the patients were tied to the stable wall in a way that prevented them from lying on their side. The first patient was initially tied to the wall using a rope which was too long, which meant it was able to acquire a lateral recumbence, but this did not have any consequences for the wound healing.

The volume of exsudate produced was quite high in both patients, especially in the case with the nodular necrobiosis (300 $\mathrm{ml}$ case 2). Whether this was a normal inflammatory reaction or was induced by the high negative pressure is unknown. In the literature no mention is made of VAC inducing exsudate formation. In the first case the volume of exsudate decreased and its aspect became hemopurulent and more viscous. Although VAC is known to reduce the bacterial count (Morykwas et al 2001), it is imaginable that with a thickening of the fluid this effect could be reduced with a risk of increased bacterial count and a decreased rate of removal of local toxins. It became clear from both patients that a canister of at least $500 \mathrm{ml}$ should be added to the drainage system when treating equine wounds, instead of the $300 \mathrm{ml}$ container provided for use in human patients.

It is advisable to change the bandage every 2 to 3 days, otherwise the granulation tissue grows into the foam resulting in bleeding at that time the foam is removed. Furthermore, when changing the foam and dressing care must be taken not to disturb the graft, because shearing can occur during graft manipulation. Therefore, bandage changes were performed, when deemed necessary, such as when air-leakage occurred, and under sedation. To prevent the ingrowth of granulation tissue the wounds were covered with a non-adhesive gauze.

The loose skin flap with underlying contaminated granulation tissue in the foal with the abdominal wound represented a complicating factor. Earlier efforts to re-attach the flap to the skin had failed. With the removal of excess interstitial fluid and exsudate the size of the skin flap and surrounding wound area were reduced, preventing loosening from the underlying tissue. Due to the increase in the rate of granulation tissue formation the flap became attached to the underlying tissue.

In the case with nodular necrobiosis two separate skin defects were present. To allow usage of one drainage system the foam on the left and right side were connected with another piece of foam. As the foam, in combination with the negative pressure, has been reported incidentally to cause a localized superficial skin irritation (Webb and Schmidt 2001) a non-adhesive gauze was positioned underneath the foam to prevent direct skin contact. No skin reactions were noticed when the bandages were changed. Initially this patient was a somewhat restless. A small percentage of human patients reported VAC treatment to be painful (Argenta 1997). The restlessness might have been due to the VAC, but could also be the result of cross-tying, or a tight abdominal bandage.

The VAC therapy was applied for 18 and 19 days respectively and was well tolerated. After 3 weeks graft acceptance was at least $75 \%$, wound contraction had decreased the size of the wound (approximately 20\%), epithelialization was clearly 
present and the loose flap had become firmly attached. After 5 weeks the wounds were epithelialized and showed functional and cosmetically acceptable healing. The positive effect is considered to be due to fixation of the graft to the recipient site, prevention of shearing forces in the graft, removal of fluid, reduction of edema, direct evenly divided contact between graft and underlying tissue, increased granulation tissue formation, improved local blood flow and decreased bacterial contamination. Although no control studies were conducted, the clinical results suggest that vacuum-assisted closure stimulates the intake of split thickness grafts and accelerates wound healing. This adjunct treatment might become an integral part in the management of large granulating wounds in the future.

\section{Acknowledgement}

The authors are grateful to $\mathrm{KCl}$ Medical B.V., Bergveste 12, 3992 DE Houten, for supporting the clinical study.

\section{Literature}

Argenta L. C. und Morykwas M. J. (1997): Vacuum assisted closure. A new method for wound control and treatment: clinical experience M.J., Ann Plast Surg. 38, 563-577

Argenta L. C. und Morykwas M. J. (2000): Vacuum assisted closure: a new method for wound control and treatment: clinical experience. Ann Plast Surg. 45, 332-334

Avery C., Pereira J., Moody A., Gargiulo M. und Whitworth I. (2000): Negative pressure wound dressing of the radial forearm donor site. International Journal of Oral \& Maxillofacial Surgery 29, 198-200

Banwell P. E. und Teot L. (2003): Topical negative pressure (TNP): the evolution of a novel wound therapy. J Wound Care. 12, 22-28

Blackburn J. H., Boemi L., Hall W. W., Jeffords K., Hauck R. M., Banducci D. R. und Graham W. P. (1998): Negative-pressure dressings as a bolster for skin grafts. Ann Plast Surg. 40, 453-457

Gemeinhardt K. D. and Molnar J. A. (2005): Vacuum-assisted closure for management of a traumatic neck wound in a horse. Equine vet Educ 17, 27-33

Hallberg H. und Holmstrom H. (2003): Vaginal construction with skin grafts and vacuum-assisted closure. Scand J Plast Reconstr Surg Hand Surg. 37, 97-101
Ilizarov G. A. (1989): The tension-stress effect on the genesis and growth of tissues: Part II. The influence of the rate and frequency of distraction. Clin Orthop Relat Res. 239, 263-285

Moisidis E., Heath T., Boorer C., Ho K. und Deva A. K. (2004): A prospective, blinded, randomized, controlled clinical trial of topical negative pressure use in skin grafting.Plast Reconstr Surg. $15 ; 114,917-722$

Morykwas M. J., Argenta L. C., Shelton-Brown E. I. und McGuirt W. (1997): Vacuum-assisted closure: a new method for wound control and treatment: animal studies and basic foundation. Ann Plast Surg 38, 553-562

Morykwas M. J., Faler B. J., Pearce D. J. und Argenta L. C. (2001): Effects of varying levels of subatmospheric pressure on the rate of granulation tissue formation in experimental wounds in swine. Ann Plast Surg.47, 547-551

Saxena V., Hwang C. W., Huang S., Eichbaum Q., Ingber D. und Orgill D. P. (2004): Vacuum-assisted closure: microdeformations of wounds and cell proliferation. Plast Reconstr Surg. 114, 10861096

Schneider A. M., Morykwas, M. J. and Argenta L. C. (1998): A new and reliable method of securing skin grafts to the difficult recipient bed. Plast. Reconstr. Surg. 102, 1195-1198

Wackenfors A., Sjogren J., Gustafsson R., Algotsson L., Ingemansson R. und Malmsjo M. (2004): Effects of vacuum-assisted closure therapy on inguinal wound edge microvascular blood flow. Wound Repair Regen.12, 600-606.

Webb LX, Schmidt U. (2001) Wound management with vacuum therapy. Unfallchirurg. 104(10):918-926

Wilmink J. M. (2005) The Meek technique as novel technique for skin grafting in horses: evaluation of acceptance and the effect on wound contraction and wound closure. Proc. Voorjaarsdagen 2005

Astrid B. M. Riikenhuizen DVM PhD Dipl ECVS,

Department of Equine Sciences,

Faculty of Veterinary Medicine,

Utrecht University,

Yalelaan 12,

3584 CM Utrecht,

The Netherlands

a.rijkenhuizen@vet.uu.nl 